\title{
Assessment of Genetic Diversity in Iranian Fennels Using ISSR Markers
}

\author{
Kaivan Bahmani ${ }^{1}$, Ali Izadi-Darbandi ${ }^{1}$, Ali Ashraf Jafari ${ }^{2}$, Seyed Ahmad Sadat Noori ${ }^{1} \&$ Mostafa Farajpour $^{1}$ \\ ${ }^{1}$ Department of Agronomy and Plant Breeding sciences, College of Aburaihan, University of Tehran, Tehran, Iran \\ ${ }^{2}$ Iranian Research Institute of Forests and Rangelands, Karaj, Iran \\ Correspondence: Ali Izadi-Darbandi, Department of Agronomy and Plant Breeding sciences, College of \\ Aburaihan, University of Tehran, Tehran, Iran. Tel: 98-292-304-0615. E-mail: aizady@ut.ac.ir
}

Received: April 26, $2012 \quad$ Accepted: May 10, $2012 \quad$ Online Published: July 26, 2012
doi:10.5539/jas.v4n9p79

\begin{abstract}
Fennel (Foeniculum vulgare Mill.) is an important medicinal plant with used for various purposes in different industries. In this study 25 different ecotypes of fennel from all over Iran were collected and their genetic diversity studied by seven ISSR primers. Seven ISSR primers generated 52 amplified fragments, of which 49 were polymorphic. The highest similarity coefficient among the ecotypes was between Chahestan and Haji abad whereas the minimum similarity coefficient observed between Fozveh and Moqan. In most cases, classifications were consistent with their geographical distribution for some ecotypes (like Givi and Khalkhal in close distance) and although with similarity in climate (like Damavand and Alamot with same climate). This study revealed that ISSR marker could properly separate these ecotypes based on geographical distribution and similarity in climates and showed the wide genetic diversity among Iranian fennels. In term of conservation program, it is highly recommended at least one conservation program for several accessions with near genetical distance should be conducted.
\end{abstract}

Keywords: Foeniculum vulgare Mill, genetic diversity, ISSR

\section{Introduction}

Bitter Fennel (Foeniculum vulgare Mill.) known as Raziyane in Persian is one of the oldest herbs and possesses beneficial medicinal effects, belongs to the Apiaceae family and native to Mediterranean regions (Hornok, 1992).

Fennel is used for various purposes in the food, cosmetic, and medical industries. Fennel essential oil has a valuable antioxidant, and has antibacterial, anticancer and antifungal activity (Lucinewton et al., 2005; El-Awadi \& Esmat, 2010). The increasing commercial value of fennel necessitates the need to identification, recognizing and conservation the existing diversity.

Genotype, environment and genotype by environment $(\mathrm{G} * \mathrm{E})$ interactions are major factors that influence phenotypic diversity in plants (Olle \& Bender, 2010; Hadian et al., 2010). Fennel has been cultivated as a medicinal and spice plant for a long time in different areas of Iran and, due to adaptation to the local environments; different genotypes show genetic diversity (Heywood, 2002). Knowledge of present diversity can guide appropriate selection schemes for taxonomic and breeding programs and also in conservation programs in fennel (Judzentiene \& Mockute, 2010).

In recent years, DNA-based molecular markers have been used for assessment of the genetic diversity between germplasm in many plant species. Inter simple sequence repeat (ISSR) markers (Zietkiewicz et al., 1994) have been used with success to identify and determine relationships at the species, population and cultivar levels in many plant species, including several aromatic and medicinal plants (e.g. Sangwan et al., 1999; Nan et al., 2003). This method is widely applicable because there are rapid, inexpensive, require small amounts of template DNA and, unlike SSR markers, do not require prior knowledge of DNA sequences (Godwin et al., 1997).

ISSR markers have been efficiently used for study of genetic diversity of different medicinal plant species and crops such as Phaseolus vulgaris L. (Galvan et al., 2003), barley (Yong-Cui et al, 2005), Artemisia capillaries (Shafie et al, 2009), Lippia alba Mill. (Manica-Cattani et al, 2009) and Achillea millefolium (Farajpour et al, 
2012). Genetical diversity of some fennel ecotypes of Pakistan have been investigated by Zahid et al (2009) using RAPD molecular markers and showed a considerable genetical diversity in Pakistani fennels.

The present work aimed to determine the efficiency of ISSR marker for the identification of genetical diversity in Iranian fennels.

\section{Material and Methods}

\subsection{Plant Materials and DNA Isolation}

A total of 25 ecotypes of bitter fennel (Foeniculum vulgare Mill) from 25 Iranian locations consisting of different climates (with different features in term of humidity, temperature, altitude and longitude) were collected (Table 1). The seeds were sawed in pots and at the length of $30 \mathrm{~cm}$ of height, sampling for DNA extracting was done. All plant materials were frozen in liquid nitrogen immediately after harvesting then was transferred to genomic lab. Total genomic DNA was extracted from frozen leaves (30 mg per ecotype) following the CTAB procedure according to Murray and Thompson (1980) with minor modifications. The A260/280 ration ranged between 1.8 and 1.9 DNA integrity was confirmed by gel electrophoresis on $0.8 \%$ agarose on TBE buffer (50 mM Tris, $50 \mathrm{Mm}$ boric acid, $2.5 \mathrm{mM}$ EDTA, $\mathrm{pH} 8.3$ ). DNA content was quantified using spectrophotometer and diluted to a $2 \mathrm{ng} / \mu \mathrm{L}$ working solution.

Table 1. Geography profile of Fennel collecting origins Foeniculum vulgare

\begin{tabular}{cccccccc}
\hline genotypes & Latitude & Longitude & Altitude $(\mathrm{m})$ & genotypes & Latitude & Longitude & Altitude $(\mathrm{m})$ \\
\hline Chahestan & $2713 \mathrm{~N}$ & $5622 \mathrm{E}$ & 27 & Qazvin & $3615 \mathrm{~N}$ & $500 \mathrm{E}$ & 1278 \\
Alamot & $3645 \mathrm{~N}$ & $5047 \mathrm{E}$ & 1500 & Tafresh & $3441 \mathrm{~N}$ & $501 \mathrm{E}$ & 1978 \\
Arak & $346 \mathrm{~N}$ & $4946 \mathrm{E}$ & 1708 & Sarpol zahab & $3427 \mathrm{~N}$ & $4554 \mathrm{E}$ & 548 \\
Khash & $2813 \mathrm{~N}$ & $6112 \mathrm{E}$ & 1394 & Fozveh & $3236 \mathrm{~N}$ & $5126 \mathrm{E}$ & 1612 \\
Fasa & $2858 \mathrm{~N}$ & $5341 \mathrm{E}$ & 1288 & Sari & $3633 \mathrm{~N}$ & $530 \mathrm{E}$ & 23 \\
Hasht gerd & $3565 \mathrm{~N}$ & $5043 \mathrm{E}$ & 1426 & Rafsanjan & $3025 \mathrm{~N}$ & $5554 \mathrm{E}$ & 1580 \\
Meshkin shahr & $3823 \mathrm{~N}$ & $4740 \mathrm{E}$ & 1568 & Givi & $3741 \mathrm{~N}$ & $4828 \mathrm{E}$ & 1682 \\
Damavand & $3543 \mathrm{~N}$ & $5215 \mathrm{E}$ & 2000 & Kaleibar & $3852 \mathrm{~N}$ & $471 \mathrm{E}$ & 1180 \\
Inche boron & $3753 \mathrm{~N}$ & $5557 \mathrm{E}$ & 460 & Khalkhal & $3738 \mathrm{~N}$ & $4831 \mathrm{E}$ & 1769 \\
Hamedan & $3451 \mathrm{~N}$ & $4832 \mathrm{E}$ & 1749 & Marvdasht & $2980 \mathrm{~N}$ & $5283 \mathrm{E}$ & 1502 \\
Yazd & $3154 \mathrm{~N}$ & $5424 \mathrm{E}$ & 1230 & Moqhan & $3939 \mathrm{~N}$ & $4755 \mathrm{E}$ & 31 \\
Ardabil & $3815 \mathrm{~N}$ & $4817 \mathrm{E}$ & 1332 & Tehran & $3541 \mathrm{~N}$ & $5119 \mathrm{E}$ & 1190 \\
Haji abad & $2819 \mathrm{~N}$ & $5555 \mathrm{E}$ & 931 & - & - & - & - \\
\hline
\end{tabular}

\subsection{Primers}

7 ISSR primers were used. The characteristics of 7 ISSR primers were shown in Table 2.

Table 2. Number of polymorphic bands of ISSR primers used for 25 ecotypes of fennel

\begin{tabular}{ccccccccc}
\hline ISSR & sequence & annealing temperature & $\begin{array}{c}\text { Number } \\
\text { of bands }\end{array}$ & $\begin{array}{c}\text { Number of } \\
\text { polymorphic } \\
\text { band }\end{array}$ & $\begin{array}{c}\text { Polymorphic } \\
(\%)\end{array}$ & Pic & $\begin{array}{c}\text { GC } \\
\text { content }\end{array}$ \\
\hline 1 & $5^{\prime}-(\mathrm{CA})_{8} \mathrm{G}-3^{\prime}$ & 52 & 8 & & 8 & 100 & 0.85 & $53 \%$ \\
2 & $5^{\prime}-(\mathrm{AG})_{8} \mathrm{YT}^{\prime} 3^{\prime}$ & 49 & 9 & 8 & 89 & 0.88 & $44 \%$ \\
3 & $5^{\prime}-(\mathrm{AG})_{8} \mathrm{~T}-3^{\prime}$ & 53 & 7 & 6 & 85 & 0.84 & $47 \%$ \\
4 & $5^{\prime}-(\mathrm{GA})_{8} \mathrm{~T}^{\prime} 3^{\prime}$ & 48 & 9 & 9 & 88 & 0.86 & $47 \%$ \\
5 & $5^{\prime}-(\mathrm{CT})_{8} \mathrm{RG}-3^{\prime}$ & 48 & 5 & 5 & 100 & 0.75 & $50 \%$ \\
6 & $5^{\prime}-\mathrm{DBD}(\mathrm{AC})_{7}-3^{\prime}$ & 49 & 8 & 5 & 62 & 0.85 & $47 \%$ \\
7 & $5^{\prime}-(\mathrm{AG})_{8} \mathrm{RC}-3^{\prime}$ & 52 & 8 & 8 & 100 & 0.86 & $50 \%$ \\
Average & - & - & 7.71 & 7 & 89 & - & - \\
Total & - & - & 54 & 49 & - & - & - \\
\hline
\end{tabular}

\section{$2.3 P C R$}

The ISSR amplification reactions (final volume of $20 \mu \mathrm{l}$ ) contained: $7.9 \mu \mathrm{l}$ Distilled water, $2 \mu \mathrm{l}$ PCR buffer, 0.5 $\mu \mathrm{l}$ of each dNTP, $0.5 \mu \mathrm{MgCl}_{2}, 1 \mu \mathrm{l}$ primer, $0.1 \mathrm{U}$ Taq-polymerase and $8 \mathrm{ng}$ of plant DNA. The amplification 
conditions for ISSR was an initial denaturing of 4 min at $94{ }^{\circ} \mathrm{C}$ followed by 40 cycles of 1 min at $94{ }^{\circ} \mathrm{C}$ for denaturing, $1 \mathrm{~min}$ for annealing (according to primer: $48-53{ }^{\circ} \mathrm{C}$ ), and $2 \mathrm{~min}$ at $72{ }^{\circ} \mathrm{C}$ for extension, and a final extension of $5 \min 72^{\circ} \mathrm{C}$ (Table 3 ).

Table 3. Details of the PCR reaction

\begin{tabular}{cccc}
\hline step & temperature (c & time $(\min )$ & cycle number \\
\hline Initial denaturing & 94 & 4 & 1 \\
denaturing & 94 & 1 & 40 \\
annealing & $48-53$ & 1 & 40 \\
extension & 72 & 2 & 40 \\
final extension & 72 & 5 & 1 \\
\hline
\end{tabular}

Amplification products were resolved by electrophoresis in 1.5\% agarose gels in TBE buffer under a constant voltage of $100 \mathrm{~V}$. DNA fragments were stained with $1 \mu \mathrm{g} . \mathrm{mL}-1$ ethidium bromide and digitalized under UV light for further analysis. Bacteriophage Lambda cut with EcoRI and HindIII was included as size standard on each gel.

\subsection{Data Analysis}

The bands were assigned molecular weights based upon their positions relative to a ladder. ISSR amplicons were scored for presence or absence in each ecotype, and the data were entered into a binary matrix as discrete variables (' 1 ' presence and ' 0 ' absence). The polymorphism information content (PIC) of each primer was expressed using this formula: $\mathrm{H}_{\mathrm{e}}=1-\sum \mathrm{P}_{\mathrm{i}}^{2}$, where $\mathrm{H}_{\mathrm{e}}$ is polymorphism information content (PIC), and pi is the frequency of the ith allele (Anderson et al, 1993). For all pairs of genotypes, genetic similarity values were calculated using the Jaccard coefficient (Sneath and Sokal, 1973), which does not include 0-0 matches as an indicator of similarity. Using genetic similarity matrices, a dendrogram was constructed according to the unweighted pair-group method with arithmetic average (UPGMA) using SPSS 18.

\section{Results and Discussion}

Seven ISSR primers generated 52 amplified fragments, of which 49 were polymorphic (Table 2). Primer 5 resulted in the smallest number of bands (5) and primers 2 and 4 generated the largest number of bands (9). The size of amplification product varied between 300 and 2,500 bp with an average size of 950bp. The highest amounts of polymorphism were observed in 1, 5 and 7 primers (Table 2).

Estimated genetic similarity based on the Jaccard coefficient for all accessions are represented in Table 4.

Table 4. Similarity coefficients of the 25 ecotypes of fennel based on ISSR data

\begin{tabular}{|c|c|c|c|c|c|c|c|c|c|c|c|c|c|c|c|c|c|c|c|c|c|c|c|c|c|c|}
\hline & & 1 & 2 & 3 & 4 & 5 & 6 & 7 & 8 & 9 & 10 & 11 & 12 & 13 & 14 & 15 & 16 & 17 & 18 & 19 & 20 & 21 & 22 & 23 & 24 & 25 \\
\hline 1 & chahestan & 1 & & & & & & & & & & & & & & & & & & & & & & & & \\
\hline 2 & alamor & 0.48 & 1 & & & & & & & & & & & & & & & & & & & & & & & \\
\hline 3 & ark & 0.67 & 0.6 & 1 & & & & & & & & & & & & & & & & & & & & & & \\
\hline 4 & khash & 0.83 & 0.41 & 0.59 & 1 & & & & & & & & & & & & & & & & & & & & & \\
\hline 5 & fase & 0.79 & 0.49 & 0.76 & 0.71 & 1 & & & & & & & & & & & & & & & & & & & & \\
\hline 6 & hasht gerd & 0.47 & 0.33 & 0.53 & 0.48 & 0.61 & 1 & & & & & & & & & & & & & & & & & & & \\
\hline 7 & mesblkin shahr & 0.61 & 0.39 & 0.53 & 0.53 & 0.65 & 0.57 & 1 & & & & & & & & & & & & & & & & & & \\
\hline 8 & damsiand & 0.59 & 0.63 & 0.56 & 0.56 & 0.59 & 0.62 & 0.45 & 1 & & & & & & & & & & & & & & & & & \\
\hline 9 & incheboron & 0.53 & 0.37 & 0.59 & 0.42 & 0.61 & 0.48 & 0.58 & 0.56 & 1 & & & & & & & & & & & & & & & & \\
\hline 10 & hamedan & 0.58 & 0.29 & 0.5 & 0.5 & 0.57 & 0.54 & 0.58 & 0.47 & 0.59 & 1 & & & & & & & & & & & & & & & \\
\hline 11 & yaxd & 0.45 & 0.32 & 0.52 & 0.47 & 0.5 & 0.34 & 0.45 & 0.39 & 0.47 & 0.38 & 1 & & & & & & & & & & & & & & \\
\hline 12 & andabil & 0.42 & 0.38 & 0.52 & 0.35 & 0.54 & 0.27 & 0.5 & 0.24 & 0.43 & 0.47 & 0.43 & 1 & & & & & & & & & & & & & \\
\hline 13 & haji abad & 0.9 & 0.45 & 0.59 & 0.74 & 0.71 & 0.44 & 0.58 & 0.61 & 0.54 & 0.65 & 0.47 & 0.43 & 1 & & & & & & & & & & & & \\
\hline 14 & qazvin & 0.67 & 0.41 & 0.54 & 0.64 & 0.61 & 0.48 & 0.58 & 0.56 & 0.59 & 0.65 & 0.38 & 0.43 & 0.74 & 1 & & & & & & & & & & & \\
\hline 15 & tafresh & 0.63 & 0.43 & 0.7 & 0.6 & 0.67 & 0.6 & 0.5 & 0.63 & 0.65 & 0.61 & 0.4 & 0.44 & 0.6 & 0.56 & 1 & & & & & & & & & & \\
\hline 16 & sarpolzahab & 0.56 & 0.48 & 0.53 & 0.62 & 0.64 & 0.47 & 0.47 & 0.59 & 0.49 & 0.41 & 0.33 & 0.46 & 0.49 & 0.57 & 0.58 & 1 & & & & & & & & & \\
\hline 17 & forveh & 0.53 & 0.4 & 0.6 & 0.45 & 0.63 & 0.38 & 0.48 & 0.38 & 0.5 & 0.5 & 0.46 & 0.52 & 0.55 & 0.66 & 0.43 & 0.44 & 1 & & & & & & & & \\
\hline 18 & sari & 0.74 & 0.42 & 0.61 & 0.71 & 0.73 & 0.61 & 0.59 & 0.58 & 0.56 & 0.67 & 0.44 & 0.4 & 0.71 & 0.83 & 0.62 & 0.59 & 0.62 & 1 & & & & & & & \\
\hline 19 & rafsenjan & 0.74 & 0.34 & 0.51 & 0.66 & 0.63 & 0.45 & 0.5 & 0.53 & 0.56 & 0.61 & 0.44 & 0.44 & 0.71 & 0.51 & 0.77 & 0.5 & 0.42 & 0.63 & 1 & & & & & & \\
\hline 20 & givi & 0.47 & 0.21 & 0.35 & 0.44 & 0.43 & 0.36 & 0.42 & 0.4 & 0.53 & 0.54 & 0.44 & 0.31 & 0.48 & 0.39 & 0.45 & 0.34 & 0.29 & 0.45 & 0.5 & 1 & & & & & \\
\hline 21 & kaleitar & 0.64 & 0.31 & 0.51 & 0.61 & 0.63 & 0.45 & 0.55 & 0.4 & 0.47 & 0.61 & 0.35 & 0.44 & 0.61 & 0.66 & 0.53 & 0.54 & 0.52 & 0.73 & 0.53 & 0.5 & 1 & & & & \\
\hline 22 & khalkhal & 0.5 & 0.29 & 0.43 & 0.52 & 0.5 & 0.35 & 0.5 & 0.39 & 0.52 & 0.47 & 0.48 & 0.39 & 0.47 & 0.43 & 0.41 & 0.46 & 0.33 & 0.48 & 0.44 & 0.75 & 0.58 & 1 & & & \\
\hline 23 & marvdashn & 0.57 & 0.38 & 0.54 & 0.54 & 0.69 & 0.44 & 0.49 & 0.43 & 0.5 & 0.46 & 0.39 & 0.47 & 0.58 & 0.58 & 0.48 & 0.53 & 0.5 & 0.56 & 0.47 & 0.32 & 0.65 & 0.43 & 1 & & \\
\hline 24 & moqhan & 0.39 & 0.22 & 0.32 & 0.36 & 0.36 & 0.32 & 0.48 & 0.28 & 0.41 & 0.5 & 0.31 & 0.32 & 0.36 & 0.29 & 0.42 & 0.28 & 0.22 & 0.33 & 0.47 & 0.61 & 0.38 & 0.58 & 0.3 & 1 & \\
\hline 25 & tehran & 0.36 & 0.36 & 0.52 & 0.38 & 0.5 & 0.8 & 0.5 & 0.48 & 0.38 & 0.41 & 0.32 & 0.33 & 0.33 & 0.38 & 0.59 & 0.41 & 0.36 & 0.48 & 0.43 & 0.24 & 0.34 & 0.25 & 0.38 & 0.35 & 1 \\
\hline
\end{tabular}


Genetic similarity within accessions was very wide and ranged from 0.22 between Fozveh and Moqan to 0.90 between Chahestan and Haji abad (Table 4). Genetic similarity was correlated with geographical distances and similarity in climate. The average similarity coefficient among all of ecotypes was $0.49 \%$.

Cluster analysis for ISSR data was performed using the between group linkage (Figure 1).

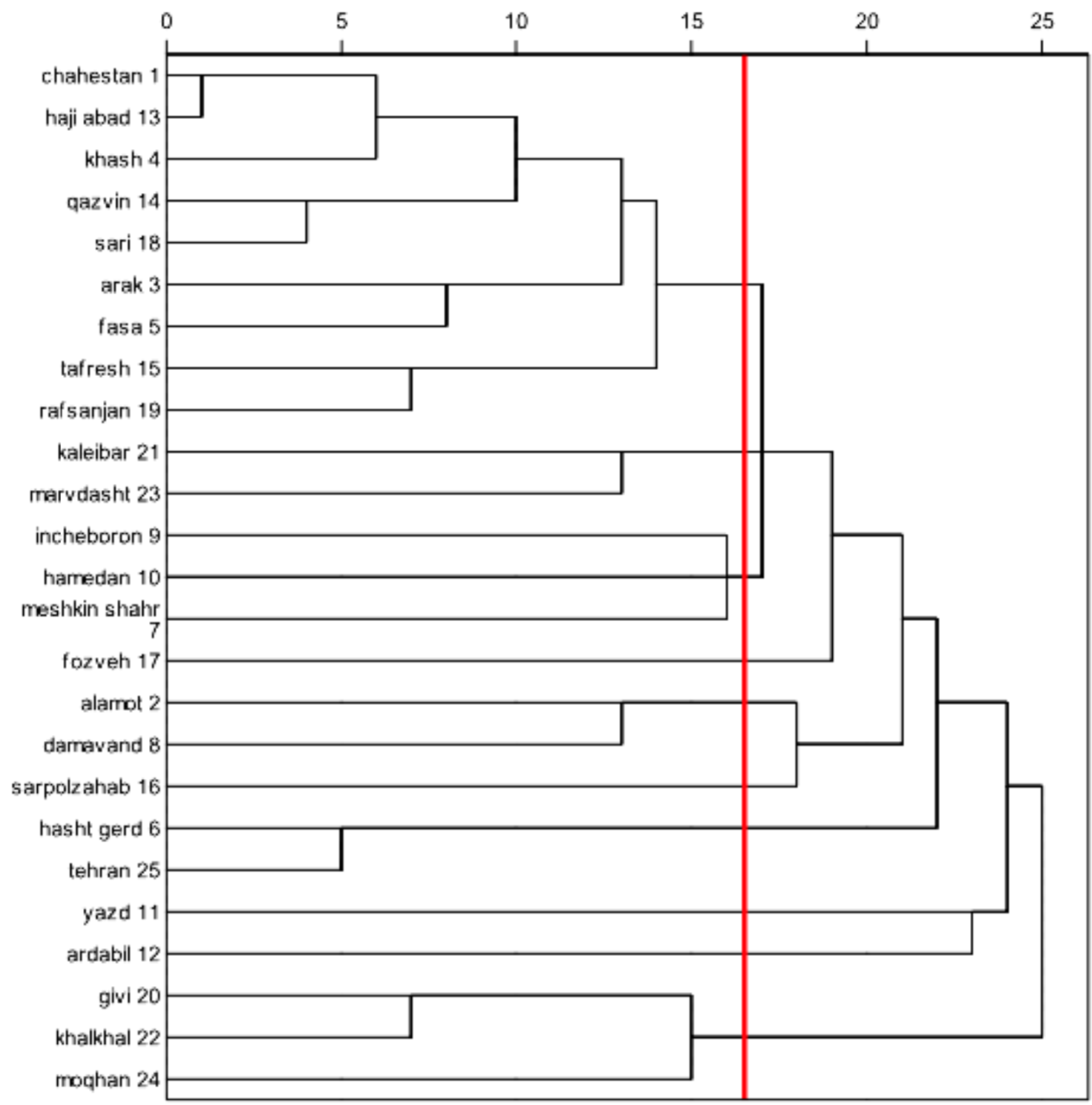

Figure 1. Clustering of 25 Iranian fennel accessions by UPGMA method

Mantel analysis between the Jaccard similarity coefficient calculated based on the presence or absence of ISSR markers showed that was medium correlated (0.79), indicating a moderate fitness between the dendrogram clusters and the similarity matrices. Cluster analysis was performed for all ISSR data using the UPGMA (Figure 1). The 25 investigated ecotypes were represented in ten main groups and this showed wide range of genetic diversity. Some ecotypes like Sari and Kaleibar and also Givi and Khalkhal were placed in same groups. Ecotypes of Haji abad, Chahestan and Khash in same group and so on.

The relationships among fennel ecotypes revealed by the grouping was somewhat congruent with their geographical distributions and similarity in climate for example ecotypes of Givi and Khalkhal in close distance are in same group and this subject comes true in ecotypes of Haji abad and Chahestan (Figure 1). Although about ecotypes of Damavand and Alamot with similar climate of wet and cool and also Hamedan and Meshkin shahr with similar climate of semi arid and cool were located in same groups and also about Arak and Fasa with dry and temperate climate. 
A relationship between genetic diversity and geographic distribution and climatic similarity has been observed in several species of aromatic plants of Anthemideae sub-family including Artemisia annua (Sangwan et al., 1999), Tanacetum vulgare (Keskitalo et al., 2001), three Achillea species (Farajpour et al., 2011) and Achillea millefolium (Farajpour et al., 2012) and this is reasonable because climate that always in near place is same, in term of genetical changes is one of the most important and effective agent on genetical information in different way (like mutation and natural selection).

The 7 ISSR primers with sufficient polymorphism these ecotypes based on their geographical and climatical properties have properly separated and it is recommendable for medicinal plants. The present study revealed the wide genetic diversity among 25 ecotypes of Iranian fennels. These results may help to understand the genetic diversity and structure of fennel with possible applications in breeding programs. F. vulgar Mill is facing great pressure because of economic activities and if some conservation measures are not adopted, the species could become endangered. Genetic diversity data are important for conservation and management of rare and endangered species. With considering of wide distribution of fennel in Iran it is highly recommended at least one conservation program for several accessions with near genetical distance (like Damavand and Alamot) should be conducted.

\section{Conclusion}

In the present study, ISSR markers provided a comprehensive insight the genetic diversity of the ecotypes of Iranian fennel. In addition, the results show that ISSR marker efficiently identified 25 ecotypes of fennel thus allowing the characterization of the ecotypes under study.

\section{References}

Anderson, J. A., Churchill, G. A., Autrique, S. D., Tanksley, S. D., \& Sorrels, M. E. (1993). Optimizing parental selection for genetic linkage maps. Genome., 36, 181-6.

El-Awadi, M. E., \& Esmat, A. H. (2010). Physiological Responses of Fennel (Foeniculum Vulgare Mill) Plants to Some Growth Substances. Journal of American Science, 6, 985-991.

Farajpour, M., Ebrahimi, M., Amiri, R., Golzari, R., \& Sanjari, S. (2012). Assessment of genetic diversity in Achillea millefolium accessions from Iran using ISSR marker. Biochem. Syst. Ecol, 43, 73-79.

Farajpour, M., Ebrahimi, M., Amiri, R., Sadat-Noori, S. H., Sanjari, S., \& Golzari, R. (2011). Study of genetic variation in yarrow using inter-simple sequence repeat (ISSR) and random amplified polymorphic DNA (RAPD) markers. Afr. J. Biotechnology, 54, 11137-11141.

Galvan, M. Z., Bornet, B., Balatti, P. A., \& Branchard, M. (2003). Inter simple sequence repeat (ISSR) markers as a tool for the assessment of both genetic diversity and gene pool origin in common bean (Phaseolus vulgaris L.). Euphytica, 132, 297-301.

Godwin, I. D., Aitken, E. A. B., \& Smith, L. W. (1997). Application of inter simple sequence repeat (ISSR) markers to plant genetics. Electrophoresis, 18, 1524-1528.

Hadian, J., Nejad-Ebrahimi, S., \& Salehi, P. (2010). Variability of morphological and phytochemical characteristics among Satureja hortensis L. accessions of Iran. Ind Crops Prod, 32, 62-69.

HeywoodV, H. (2002). The Conservation of genetic and chemical diversity in medicinal and aromatic plants. In Şener B, editor. Biodiversity: biomolecular aspects of biodiversity and innovative utilization. Heidelberg, 2, $13-22$.

Hornok, L. (1992). The cultivating and Processing of Medicinal Plants. John Wiley, New York. pp. 338.

Judzentiene, A., \& Mockute, D. (2010). Essential oil composition of two yarrow taxonomic forms. Central European Journal of Biology. http://dx.doi.org/10.2478/s11535-010-0011-7

Keskitalo, M., Pehu, E., \& Simon, J. E. (2001). Variation in volatile compounds from tansy (Tanacetum vulgare L.) related to genetic and morphological differences of genotypes. Biochem. Syst. Ecol., 29, 267-285.

Lucinewton, S., Raul, N., Carvalho, J., Mirian, B., Lin, C., \& Angela, A. (2005). Supercritical fluid extraction from fennel (Foeniculum vulgare) global yield, composition and kinetic data. J. of Supercritical Fluids, 35, 212-219.

Manica-Cattani, M. F., Zacaria, J. G., Pauletti, L., Atti-Serafini, A., \& Echeverrigaray, S. (2009). Genetic variation among South Brazilian accessions of Lippia alba Mill. (Verbenaceae) detected by ISSR and RAPD markers. Braz. J. Biol, 69, 375-380. 
Murray, M. G., \& Thompson, W. F. (1980). RAPD isolation of high molecular weight plant DNA. Nucleic Acids Res, 8, 4321-4326.

Nan, P., Peng, S., Shi, S., Ren, H., Yang, J., \& Zhong, Y. (2003). Interpopulation congruence in Chinese Primula ovalifolia revaled by chemical and molecular markers using essential oils and ISSRs. Zeitschrift für Naturforschung. Journal of biosciences, 58, 57-61.

Olle, M., \& Bender, I. (2010). The content of oils in umbelliferous crops and its formation. Agronomy Research, 8 , 687-696.

Sangwan, R. S., Sangwan, N. S., Jain, D. C., Kumar, S., \& Ranade, A. S. (1999). RAPD profile based genetic characterization of chemotypic variants of Artemisia annua L. Biochem. Mol. Biol. Int, 47, 935-944.

Shafie, M. B., Sayed, S. M., Hasan, Z., \& Shah, R. M. (2009). Study of genetic variability of Wormwood capillary (Artemisia capillaris) using inter simple sequence repeat (ISSR) in Pahang region, Malaysia. Plant Omics Journal, 2, 127-13.

Sneath, P., \& Sokal, R. R. (1973). Numerical taxonomy. San Francisco: Freeman.

Yong-Cui, H., Ze-Hong, Y., Yu-Ming, W., \& You-Liang, Z. (2005). Genetic diversity in barley from west China based on RAPD and ISSR analysis. Barley Genetics Newsletter, 35, 9-22.

Zahid, N. Y., Abbasi, N. A., Hafiz, I. A., \& Ahmad, Z. (2009). Genetic Diversity of Indigenus Fennel (Foeniculum Vulgare Mill.) Germplasm in Pakistan Assessed by RAPD Markers. Pak. J. Bot, 41, 1759-1767.

Zietkiewicz, E., Rafalski, A., \& Labuda, D. (1994). Genome fingerprinting by simple Sequence Repeat (SSR): anchored polymerase chain reaction amplification. Genomics, 20, 176-183. 